Bull. Chem. Soc. Ethiop. 2019, 33(3), 541-549.

ISSN 1011-3924

(C) 2019 Chemical Society of Ethiopia and The Authors

Printed in Ethiopia

DOI: https://dx.doi.org/10.4314/bcse.v33i3.14

\title{
CHEMICAL COMPOSITION, ANTIMICROBIAL, ANTIOXIDANT AND ANTICANCER ACTIVITIES OF ESSENTIAL OIL FROM AMMODAUCUS LEUCOTRICHUS COSSON \& DURIEU (APIACEAE) GROWING IN SOUTH ALGERIA
}

\author{
Benchikha Naima $^{1 *}$, Rebiai Abdelkrim ${ }^{1}$, Brahmia Ouarda $^{2}$, Neghmouche Nacer Salah $^{1}$ \\ and Ben Amor Mohmmed Larbi ${ }^{1}$ \\ ${ }^{1}$ University of El-Oued, Department of chemistry, P.O. Box 789, 39000, El-Oued, Algeria \\ ${ }^{2}$ University of Constantine 1, Laboratory of Innovative Techniques for Environment \\ Preservation, Algeria
}

(Received April 22, 2019; Revised May 24, 2019; Accepted May 25, 2019)

\begin{abstract}
The chemical composition of the essential oil obtained by hydrodistillation from aerial parts of $A$. leucotrichus Cosson \& Durieu (Apiaceae) grown in the south of Algeria (El-Oued) was determined by GC-MS analysis. The oil was found to be rich in perilladehyde $64.66 \%$ and D-Limonene $26.99 \%$. The biological activity of $A$. leucotrichus Cosson \& Durieu essential oil has been investigated. The in vitro antimicrobial activity of the essential oil sample was tested on eight strains, one yeast and one fungi. The test showed interesting antimicrobial properties, especially on Salmonella enterica and E. coli, the antioxidant capacity of the oil was measured using the cyclic voltammetry, and the AAT value of $A$. leucotrichus essential oil was evaluated $47.84 \mathrm{mg} \alpha-\mathrm{TE} / \mathrm{L}$. In addition, the antitumor activity showed that the oil of A. leucotrichus was very significant against the HCT116 colon cancer cell line.
\end{abstract}

KEY WORDS: Ammodaucus leucotrichus, Antioxidant activity, Anticancer activity, Cyclic voltammetry

\section{INTRODUCTION}

Ammodaucus leucotrichus Cosson \& Durieu belonging to Apiaceae family, is one of the huge plant's diversity of the Sahara desert [1]. It is a small annual plant, 10-12 cm in height, glabrous with erect, finely striates stems [2]. The leaves are finely dissected and slightly fleshy. The flowers are grouped in umbels of 2 to 4 bran. The flowers are small, with five free petals. The fruit is a diachene, $6-10 \mathrm{~mm}$, long and is covered with dense silky white hairs. It usually flowers in early spring (February to April). The plant is common in the Algerian Sahara (El-Oued) [3]. In the Algerian traditional medicine, A. leucotrichus is used for the treatment of common cold and fever [4], stomach diseases, vomiting pains and allergies [5]. Moreover, emmenagogue, abortive and aphrodisiac properties are attributed to this species. The flowers are used for the treatment of cardiac diseases [6]. A. leucotrichus seeds decoction plays an important role in traditional medicine in North African countries (Algeria, Morocco, Tunisia, Libya, Egypt, Mauritania and upper Niger valley). Its best implantation is in desert regions, often down a hill or a dune [7]. The leaves are used to aromatize tea. Powdered, it is much-appreciated as a spice food in the El-Oued area [8]. Even though, this plant is known to grow wild in Algeria and in spite of its wide uses in traditional medicine, a full investigation of the chemical composition of the essential oil extracted from the aerial parts, has never been mentioned before. This study is considered as the first original report giving full details of the composition as well as the antimicrobial, anticancer and antioxidant properties using spectrophotometrical (DPPH) and electrochemical methods (cyclic voltammetry) of the aerial parts oil obtained from Ammodaucus leucotrichus Coss \& Dur, to effectively exploit of the usage of this plant. The essential oil was also evaluated for its anticancer activity against HePG2 (Hepatic) and HCT116 (Colon) human cancerous cell lines.

*Corresponding author.naima_chem@yahoo.fr

This work is licensed under the Creative Commons Attribution 4.0 International License 


\section{Plant material}

\section{EXPERIMENTAL}

The plant material of Ammodaucus leucotrichus was obtained from the valley state of southeast Algeria, in February 2018. Then, we washed it thoroughly with water, and it was left to dry in the shade for 15 days. Voucher specimens (NOR-018) were deposited to the Herbarium of the chemistry laboratory, University of El-Oued.

\section{Essential oil extraction}

The aerial parts of the plant were subjected to hydrodistillation for $3 \mathrm{~h}$ using a Clevenger-type apparatus. The oil obtained was collected and dried over anhydrous sodium sulfate $\mathrm{Na}_{2} \mathrm{SO}_{4}$ to remove moisture. Then, it was stored at $4{ }^{\circ} \mathrm{C}$ in sealed brown vials until analysis. The oil analysis was carried out using GC-MS.

Gas chromatography-mass spectrometry (GC-MS) analysis

Mass spectra were recorded using Shimadzu GCMS-QP2010 (Tokyo, Japan) equipped with Rtx-5MS fused bonded column ( $30 \mathrm{~m}$ x $0.25 \mathrm{~mm}$ i.d. x $0.25 \mu \mathrm{m}$ film thickness) (Restek, USA) equipped with a split-splitless injector. The capillary column was directly coupled to a quadrupole mass spectrometer (SSQ 7000; Thermo-Finnigan, Bremen, Germany). The initial column temperature was kept at $45{ }^{\circ} \mathrm{C}$ for $2 \mathrm{~min}$ (isothermal) and programmed to $300{ }^{\circ} \mathrm{C}$ at a rate of $5{ }^{\circ} \mathrm{C} / \mathrm{min}$, and kept constant at $300{ }^{\circ} \mathrm{C}$ for $5 \mathrm{~min}$ (isothermal). The injector temperature was $250{ }^{\circ} \mathrm{C}$. Helium carrier gas flow rate was $1.41 \mathrm{~mL} / \mathrm{min}$. All mass spectra were recorded applying the following conditions: (equipment current) filament emission current, $60 \mathrm{~mA}$; ionization voltage, $70 \mathrm{eV}$; ion source, $200{ }^{\circ} \mathrm{C}$. Diluted samples $(1 \% \mathrm{v} / \mathrm{v})$ were injected with split mode (split ratio 1: 15).

\section{Compounds identification}

The determination of oil components was based on comparing their spectra with those of references in the MS Library (NIST and Wiley). To confirm the identification, the corresponding retention indexes (RI) were calculated using the n-alkanes series, $\mathrm{C}_{8}-\mathrm{C}_{28}$, and then compared with those reported in the literature [9]. The relative amounts of individual components were calculated based on GC-FID peak area.

Cytotoxic effect on cancerous cell lines

The cytotoxic activity test (in vitro bioassay on human tumor cell lines) was conducted and determined by the Bioassay-Cell Culture Laboratory, National Research Centre, El-Tahrir St., Dokki, Cairo 12622, Egypt. In this study, we evaluated the cell viability by the mitochondrial dependent reduction of yellow MTT (3-(4,5-dimethylthiazol-2-yl)-2,5-diphenyltetrazolium bromide) to purple formazan [10]. It is to note that the following procedures were conducted in an aseptic zone using a laminar flow room biosafety class II level (Baker, SG403INT, Sanford, ME, USA). The cells were suspended in RPMI 1640 medium (for HePG2 and HCT116), 1\% antibiotic-antimycotic mixture $(10,000 \mathrm{U} / \mathrm{mL}$ potassium penicillin, $10,000 \mu \mathrm{g} / \mathrm{mL}$ streptomycin sulfate and $25 \mu \mathrm{g} / \mathrm{mL}$ Amphotericin B) and $1 \%$ L-glutamine at $37{ }^{\circ} \mathrm{C}$ under $5 \% \mathrm{CO}_{2}$. Concentration of $10 \times 103$ cells/well in complete and fresh culture medium in 96-well plastic microtiter plates at $37{ }^{\circ} \mathrm{C}$ for 24 hours under $5 \% \mathrm{CO}_{2}$, using a carbon dioxide incubator (Sheldon, TC2323), Cornelius, OR, USA. The medium was aspirated, the fresh one (no serum) was added and the cells were incubated either alone (negative control) or with different sample concentrations to give a final concentration of (-0.78-1.56-3.125-6.25-12.5-25-50-100) $\mu \mathrm{g} / \mathrm{mL}$. After $48 \mathrm{~h}$ of incubation, the medium was aspirated, $40 \mu \mathrm{L}$ of MTT salt $(2.5 \mu \mathrm{g} / \mathrm{mL})$ was added 
to each well and incubated for a further four hours at $37{ }^{\circ} \mathrm{C}$ under $5 \% \mathrm{CO}_{2}$. To stop the reaction and dissolve the formed crystals, $200 \mu \mathrm{L}$ of $10 \%$ sodium dodecyl sulfate (SDS) in deionized water were added to each well and incubated overnight at $37^{\circ} \mathrm{C}$. A positive control consisting of $100 \mu \mathrm{g} / \mathrm{mL}$ was used as a known natural cytotoxic agent, giving $100 \%$ lethality under the same conditions $[11,12]$. The absorbance was then measured using a multi-well microplate reader (Bio-Rad Laboratories Inc., Model 3350, and Hercules, California, USA) at $595 \mathrm{~nm}$ and a reference wavelength of $620 \mathrm{~nm}$. Statistical significance was tested between the samples and the negative control (cells with vehicle) using an independent t-test by the SPSS 11 program. DMSO is the vehicle used for the dissolution of the plant extracts, and its final concentration in the cells was less than $0.2 \%$. The percentage change in viability was calculated using the following formula (1):

Cell viability $(\%)=($ Extract reading/Negative control reading $) \times 100$.

A probit analysis was carried out to determine $\mathrm{IC}_{50}$ and $\mathrm{IC}_{90}$ using the SPSS 11 program.

Antioxidant capacity

Cyclic voltammetry method

The determination of antioxidant capacity was based on cyclic voltammetry (CV) experiments were performed using PGZ402 potentiostat/galvanostat (radiometer analytical SAS) controlled with the VoltaMaster4 software version 7.08 (radiometer analytical SAS). Experiments were realized in a double walled electrochemical cell of $25 \mathrm{~mL}$, and conventional three electrodes system was employed. We used a glassy carbon (GC) working electrode (radiometer analytical SAS), with an area of $0.013 \mathrm{~cm}^{2}$, a platinum wire counter electrode, and an $\mathrm{Hg} / \mathrm{Hg}_{2} \mathrm{Cl}_{2}$ reference electrode $(3.0 \mathrm{M} \mathrm{KCl})$. Prior to the voltammetric experiments, the glassy carbon electrode was cleaned with cotton soaked in acetone for $2 \mathrm{~min}$, and then with cotton soaked in water for several seconds. A toluene-ethanolic (50\% ethanol, v/v) was used as solvent and $10 \mu \mathrm{L}$ sulfuric acid as supporting electrolyte. All solutions were prepared using absolute ethanol. Once we cleaned the GC electrode, the required sample volume (of $\alpha$-tocopherol solution or Ammodaucus leucotrichus oil) was added by micro-pipette into the supporting electrolyte in the electrochemical cell. The cyclic voltammograms were immediately recorded to minimize adsorption (or avoid any other electrochemically active species) onto the GC electrode surface. The cyclic voltammetric conditions used were: scans ranged from 0 to $+1 \mathrm{~V}$; scan rate of 100 $\mathrm{mV} . \mathrm{s}^{-1}$. All measurements were done in triplicate.

\section{DPPH radical scavenging activity}

The estimation of the remaining DPPH radical concentration in DPPH solution after reaction with essential oils was performed using slightly modified procedure $[13,14]$. Pure methanol was used to adjust the zero of the spectrophotometer. Methanolic solution of the examined essential oil $(1 \mathrm{~mL})$ was mixed with DPPH solution $(1 \mathrm{~mL})$ in a $5 \mathrm{~mL}$ test tube. The mixture was stirred vigorously for $30 \mathrm{~s}$, poured into the optical cuvettes $(1 \mathrm{~cm} \times 1 \mathrm{~cm} \times 3.5 \mathrm{~cm})$ and immediately placed in a spectrophotometer. The changes of absorbance at $515 \mathrm{~nm}$ were monitored in a continuous manner during $30 \mathrm{~min}$. The percent of inhibition I (\%) was calculated from the formula (2):

$I(\%)=\left(\frac{A_{0}-A_{s}}{A_{0}}\right) \times 100$

where $A_{0}$ is the absorbance of the control (containing all reagents except the test compound) and $A_{\mathrm{s}}$ is the absorbance of tested sample. The oil concentration providing $50 \%$ inhibition $\left(\mathrm{IC}_{50}\right)$ was calculated from the graph by plotting inhibition \% against oil concentration. $\alpha$-Tocopherol was used as reference. 
Antimicrobial activity

The minimal inhibitory concentration (MIC) of essential oil values were evaluated in the Mueller Hinton Broth (MHB) by dilution method against Bacillus subtilis (B.s) (ATCC6663), Micrococcus luteus (M.l) (ATTC9314), Listeria monocytogene (L.m) (CIP82110), Escherichia coli (E.c) (CIP54.8), Klebsiella pneumonia (K.p) (CIP82.91), Pseudomonas aeruginosa (P.a) (CIPA22), Agrobacterium tumefaciens (A.t) (N²410), Salmonella enterica (S.e) (CIP 81.3), Mucor ramannianus (M.r) (NRRL6606) and Candida albicans (C.a) (CLM). An aliquot (1 mL) of this suspension was transferred to a sterile tubes of MHB containing various concentrations of oils $(0.1-15 \mu \mathrm{L})[15]$ and the volume was adjusted to $10 \mathrm{~mL}$ with ethanol $(5 \%, \mathrm{w} / \mathrm{v})$ to obtain bacterial inoculums adjusted to a concentration of $10^{6} \mathrm{CFU} / \mathrm{mL}$, which were incubated under shaking conditions (100-120 rpm) for $24 \mathrm{~h}$ at $37^{\circ} \mathrm{C}$. Each test was performed in triplicate; on three separate experiments.

\section{RESULTS AND DISCUSSION}

\section{Chemical composition}

The hydrodistillation of A. leucotrichus areal parts gave blue oil with yield of $1.8 \%$. A total of 24 components were identified and presented about $99.91 \%$ of the total detected constituents. The essential oil contained (Table 1) $64.8 \%$ of oxygenated monoterpenes and $34.86 \%$ of monoterpenes hydrocarbons. It could be noticed that the principal constituent was perillaldehyde $(64.66 \%)$, followed by D- limonene $(26.99 \%)$ and the less percentage was attributed to $\alpha$-pinene $(5.8 \%)$. At very low concentrations (less than $1 \%$ ) of other compounds were identified such as; $\beta$-pinene $0.66 \%, \beta$ - ocimene $0.65 \%$ and camphene $0.4 \%$. Methyl perillate and bornyl acetate were detected in a limited amount of $0.08 \%$.

Our results are in agreement with those reported in the literature [14, 17], except some differences related to the quantification of the essential oil major components as well as the nature of some identified constituents. For example, according to the studies of [3, 17], they both indicated the presence of only a small amount of $\alpha$-pinene, which disagree with our results [3]. In addition, indicated that Moroccan A. leucotrichus essential oil is constituted mainly of perillaldehyde $88.7 \%$ and limonene $8.26 \%$, compared with our results this species contained more perillaldehyde and fewer limonene. In addition further studies reported that A. leucotrichus essential oil extracted from seeds collected in Algeria, contained perillaldehyde $59.12 \%$ and limonene $23.89 \%$. Hence the oil originator from Algeria (El-Oued region) is the source of active component (perillaldehyde) used in generally in perfume, cosmetics and for its aroma [18].

\section{Antimicrobial activity}

In vitro investigation of $A$. leucotrichus essential oil was carried out to evaluate its biological efficiency against certain micro-organisms; Bacillus subtilis, Micrococus luteus and Lesteria monocytogene (Gram positive bacteria), Escherichia coli, Klebsiella pneumoniae, Pseudomonas aeruginosa, Agrobacterium tumefaciens and Salmonella enterica (Gram negative bacteria), Mucor ramannianus (fungus) and Candida albicans (yeast). The corresponding minimum inhibitory concentrations (MICs $(\mu \mathrm{L} / \mathrm{mL})$ ) of various micro-organisms are shown in (Table 2). The results demonstrated that essential oil under investigation possessed antimicrobial activities against the used micro-organisms.

The different results of the antimicrobial activity of this essential oil by the MIC method are shown in (Table 2). The latter method gives more reliable results compared to the disk method but requires, however, a large oil to test $[19,20]$. We can globally note the presence of an antimicrobial activity vis-à-vis the essential oil of $A$. leucotrichus. 
With regard to Gram-negative bacteria; Salmonella enterica and E. coli are the most sensitive with a lowest MIC of $5 \mu \mathrm{L} / \mathrm{mL}$. Of all Gram-negative bacteria, only Pseudomonas aeroginosa gives the highest MIC value while Micrococus luteus is the most resistant gram-positive bacteria with a MIC of $15 \mu \mathrm{L} / \mathrm{mL}$. The same table also shows that the yeast and the fungi manifest in the same manner, giving a MIC of 10 $\mu \mathrm{L} / \mathrm{mL}$. These results are in agreement with those given by [21,8] Finally, the botanical origin of the species seems to play a key role in its antimicrobial efficacy, which confirms the close relationship that exists between the chemical structures of the essential oil constituents.

Table1. Chemical composition of Ammodaucus leucotrichus essential oil.

\begin{tabular}{|c|c|c|c|}
\hline Compound & $\mathrm{ARI}^{\mathrm{a}}$ & $\mathrm{RI}^{\mathrm{b}}$ & Area $\%$ \\
\hline$\alpha$-pinene & 932 & 925 & 5.8 \\
\hline$\alpha$-Fenchene & 945 & 934 & 0.02 \\
\hline Camphene & 946 & 941 & 0.4 \\
\hline Thuja-2,4(10)-dien & 953 & 948 & 0.04 \\
\hline Sabinene & 969 & 969 & 0.03 \\
\hline$\beta$-Pinene & 974 & 972 & 0.66 \\
\hline Myrcene & 988 & 989 & 0.15 \\
\hline$\alpha$-Phellandrene & 1002 & 1003 & 0.04 \\
\hline$\beta$-Ocimene & 1009 & 1022 & 0.65 \\
\hline$p$-Cymene & 1020 & 1024 & 0.06 \\
\hline D-Limonene & 1024 & 1029 & 26.99 \\
\hline 1,3,8-p-Menthatriene & 1108 & 1122 & 0.02 \\
\hline$\alpha$-Campholenal & 1122 & 1127 & 0.02 \\
\hline Trans-Pinocarveolc & 1135 & 1141 & 0.05 \\
\hline Pentyl Benzene & 1152 & 1147 & 0.03 \\
\hline Myrtenal & 1195 & 1198 & 0.01 \\
\hline Verbenone & 1204 & 1212 & 0.02 \\
\hline Cumin aldehyde & 1238 & 1244 & 0.02 \\
\hline Carvone & 1239 & 1249 & 0.02 \\
\hline Linalool acetate & 1257 & 1257 & 0.03 \\
\hline Perillaldehyde & 1269 & 1285 & 64.66 \\
\hline Bornyl acetate & 1287 & 1291 & 0.08 \\
\hline Benzyl isobutanoate & 1297 & 1305 & 0.03 \\
\hline Methyl perillate & 1392 & 1399 & 0.08 \\
\hline $\begin{array}{l}\text { Total identified } \\
\text { Yield of essential oil }\end{array}$ & 1.8 & & 99.91 \\
\hline \multicolumn{3}{|l|}{ Monoterpene hydrocarbons } & 34.86 \\
\hline \multicolumn{3}{|l|}{ Oxygenated monoterpenes } & 64.8 \\
\hline \multicolumn{3}{|l|}{ Other Compounds } & 0.25 \\
\hline
\end{tabular}

$\mathrm{RI}^{\mathrm{b}}$ : Retention indices, $\mathrm{ARI}^{\mathrm{a}}$ : Adams retention indices.

Cytotoxic activity test

The cytotoxic activity of $A$. leucotrichus essential oil obtained by hydro-distillation was tested against the two-cell line as it happens HCT116 (colon cell line) and HePG2 (Human hepatocellular carcinoma cell line) [21]. The evaluation of cytotoxicity was performed for essential oil samples concentration that ranged between 0.78 to $100 \mu \mathrm{g} / \mathrm{mL}$ using MTT assays. The results are shown in (table 3 ). The essential oil possesses cytotoxic activity on HCT116 [21]. Hence the $\mathrm{LC}_{50}$ (lethal concentration of essential oil which causes the death of $50 \%$ of cells in $48 \mathrm{~h}$ ) and $\mathrm{LC}_{90}$ (lethal concentration of essential oil which causes the death of $90 \%$ of cells in 
$48 \mathrm{~h}$ ) was found to be $72.6 \mu \mathrm{g} / \mathrm{mL}$ and $110.6 \mu \mathrm{g} / \mathrm{mL}$, respectively. The inhibition percentage of this essential oil against HCT116 colon cancer cell line is $78.2 \%$ for $100 \mu \mathrm{g} / \mathrm{mL}$. In fact, the results are very promising compared with positive control Adrinamycin (Doxorubicin) 37.6 $\mu \mathrm{g} / \mathrm{mL}$, while the tested oil is almost ineffective against the HePG2 cell line, for $100 \mu \mathrm{g} / \mathrm{mL}$ the inhibition percentage is $11.5 \%$. Finally, the active compound in oil of A. leucotrichus for its significant cytotoxic activity especially for colon cancer is most likely the perillaldehyde and limonene, acting alone or synergetically with one or more components.

Table 2. MICs of essential oil from Ammodaucus leucotrichus.

\begin{tabular}{|c|c|c|c|c|c|c|c|c|c|c|c|c|}
\hline $\begin{array}{l}\text { Concentration } \\
(\mu \mathrm{L} / \mathrm{mL})\end{array}$ & 0.1 & 0.2 & 0.3 & 0.4 & 0.5 & 1 & 2 & 3 & 4 & 5 & 10 & 15 \\
\hline \multicolumn{13}{|l|}{ Gram + Bacteria } \\
\hline $\begin{array}{l}\text { Bacillus subtilis } \\
\text { (ATCC6663) }\end{array}$ & + & + & + & + & + & + & + & + & + & + & - & - \\
\hline $\begin{array}{l}\text { Micrococcus luteus } \\
\text { (ATTC9314) }\end{array}$ & + & + & + & + & + & + & + & + & + & + & + & - \\
\hline $\begin{array}{l}\text { Listeria monocytogene } \\
\text { (CIP82110) }\end{array}$ & + & + & + & + & + & + & + & + & + & + & - & - \\
\hline \multicolumn{13}{|l|}{ Gram - Bacteria } \\
\hline $\begin{array}{l}\text { Escherichia Coli } \\
\text { (CIP54.8) }\end{array}$ & + & + & + & + & + & + & + & + & + & - & - & - \\
\hline $\begin{array}{l}\text { Klebsiella pneumoniae } \\
\text { (CIP82.91) }\end{array}$ & + & + & + & + & + & + & + & + & + & + & - & - \\
\hline $\begin{array}{l}\text { Pseudomonas aeruginosa } \\
\text { (CIPA22) }\end{array}$ & + & + & + & + & + & + & + & + & + & + & + & - \\
\hline $\begin{array}{l}\text { Agrobacterium } \\
\text { tumefaciens }\left(\mathrm{N}^{\circ} 2410\right)\end{array}$ & + & + & + & + & + & + & + & + & + & + & - & - \\
\hline $\begin{array}{l}\text { Salmonella enterica } \\
\text { (CIP 81.3) }\end{array}$ & + & + & + & + & + & + & + & + & + & - & - & - \\
\hline \multicolumn{13}{|l|}{ Fungi } \\
\hline $\begin{array}{l}\text { Mucor ramannianus } \\
\text { NRRL } 6606\end{array}$ & + & + & + & + & + & + & + & + & + & + & - & - \\
\hline \multicolumn{13}{|l|}{ Yeast } \\
\hline Candida albicans (CLM) & + & + & + & + & + & + & + & + & + & + & - & - \\
\hline
\end{tabular}

*Note: (-), total inhibition; $(+)$, growing.

\section{Antioxidant capacity}

\section{Cyclic voltammetry method}

The CV method is actually based on the correlation between the area under the anodic curve of the voltammogram and the electroactivity of the compound under investigation [22]. To calculate the antioxidant capacity, we plotted the calibration curve (Figure 1) using the voltammogram area versus the concentrations of the $\alpha$-tocopherol (ranged between $0-450 \mathrm{mg} / \mathrm{L}$ ) used as standard. From the (Figure 1), we deduced the antioxidant capacity of Ammodaucus leucotrichus oil.

They were next applied to express the total antioxidant capacity of Ammodaucus leucotrichus oil sample as $\alpha$-tocopherol equivalent. The area under peak current of the background signal (solvent and supporting electrolyte) was subtracted from the area under peak current obtained for sample and $\alpha$-tocopherol which were recorded within the range of 0 to $+1 \mathrm{~V}$. The cyclic voltammogram of Ammodaucus leucotrichus oil sample clearly shows the antioxidant capacity estimated at a value of $47.84 \mathrm{mg} \alpha-\mathrm{TE} / \mathrm{L}$. The obtained results are significant, but less important than the antioxidant capacity showed by Origanum majorana and O. vulgare plant oils in previous studies [13]. 
Chemical composition, antimicrobial, antioxidant and anticancer activities of essential oil 547

Table 3. Cytotoxic activity of Ammodaucus leucotrichus essential oil against human cell lines.

\begin{tabular}{|c|c|c|c|c|c|c|c|c|}
\hline $\begin{array}{c}\text { Sample } \\
\text { code }\end{array}$ & $\begin{array}{c}100 \\
\mu \mathrm{g} / \mathrm{mL}\end{array}$ & $\begin{array}{c}50 \\
\mu \mathrm{g} / \mathrm{mL}\end{array}$ & $\begin{array}{c}25 \\
\mu \mathrm{g} / \mathrm{mL}\end{array}$ & $\begin{array}{c}12.5 \\
\mu \mathrm{g} / \mathrm{mL}\end{array}$ & $\begin{array}{c}\mathrm{IC}_{50} \\
(\mu \mathrm{g} / \mathrm{mL})\end{array}$ & $\begin{array}{c}\mathrm{IC}_{90} \\
(\mu \mathrm{g} / \mathrm{mL})\end{array}$ & $\begin{array}{c}\text { Doxorubicin } \\
\mathrm{IC}_{50}(\mu \mathrm{g} / \mathrm{mL})\end{array}$ & $\begin{array}{c}\text { DMSO at } \\
100 \mathrm{ppm}\end{array}$ \\
\hline HCT116 & $78.2 \pm 2.65$ & $29.17 \pm 1.41$ & $9.03 \pm 1.62$ & 0 & 72.6 & 110.4 & 37.6 & $1 \%$ \\
\hline HePG2 & 11,5 & ------ & ------ & ------ & ------ & ---- & 21.6 & $1 \%$ \\
\hline
\end{tabular}

"Each value represents the mean percentage of inhibition cells of three replicates \pm SEM (standard error mean).

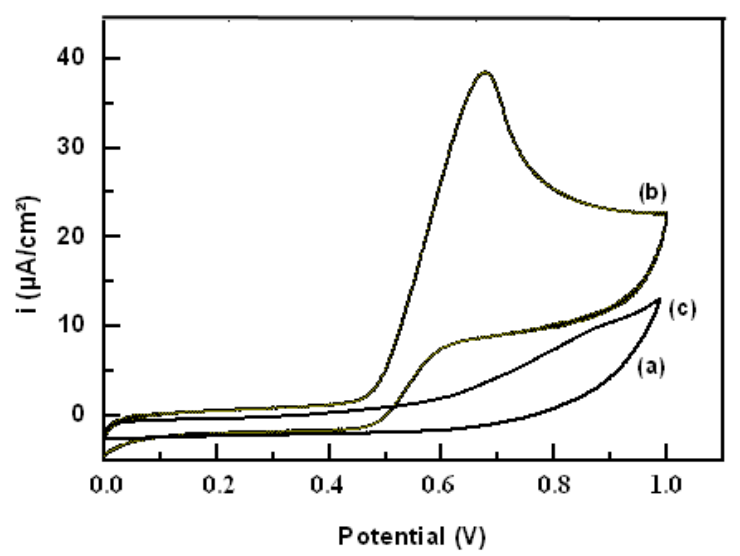

Figure 1. Cyclic voltammograms of (a) supporting electrolyte, (b) $\alpha$-tocopherol, (c) Ammodaucus leucotrichus oil.

\section{DPPH radical scavenging activity}

The essential oil of $A$. leucotrichus was explored for antioxidant activity using DPPH free radical scavenging power characterized by $\mathrm{IC}_{50}$ value. Table 4 show the percentage of DPPH inhibition of studied essential oil and $\alpha$-tocopherol as positive control measured in DPPH assay at different concentrations respectively. The essential oil exhibited a less significant scavenging effect $\mathrm{IC}_{50}=74.53 \mathrm{mg} / \mathrm{mL}$ compared to $\alpha$-tocopherol $(26.426 \mu \mathrm{g} / \mathrm{mL})$ used as positive control. The tested essential oil (Table 1$)$ is markedly rich in oxygenated monoterpenes $(64.8 \%)$ which may act as radical scavenging agents [23].

Table 4. DPPH radical scavenging Activity of standard solution (vitamin E).

\begin{tabular}{|c|c|c|c|c|c|c|c|}
\hline $\begin{array}{c}\text { Concentration } \\
(\mu \mathrm{g} / \mathrm{mL})\end{array}$ & 5 & 10 & 25 & 50 & 100 & 200 & $\begin{array}{c}\mathrm{IC} 50 \\
(\mu \mathrm{g} / \mathrm{mL})\end{array}$ \\
\hline $\mathrm{I}(\%)$ & $33.03 \pm 0.016$ & $36.62 \pm 0.002$ & $47.18 \pm 0.006$ & $92.62 \pm 0.0014$ & 100 & 100 & 26.43 \\
\hline
\end{tabular}

\section{CONCLUSION}

The present work pointed out the investigation of the chemical composition of the essential oil of A. leucotrichus growing in South Algeria on the basis of GC-MS analyzes. The results showed particularly that this oil is rich in perillaldehyde and Dlimonene, added to this; many other compounds were identified and characterized. The in vitro antimicrobial activity of the essential oil was tested on eight strains, one yeast and one fungus. The test showed interesting antimicrobial properties, especially on 
Salmonella enterica and E. coli. Moreover, A. leucotrichus essential oil exhibited significant antioxidant effects confirmed by two different methods as well as a notable anti-cancer activity with respect to the HCT116 colon cancer cell line.

\section{ACKNOWLEDGEMENT}

This work was supported by the ministry of higher education and scientific research of Algeria (project number B00L01UN390120180001).

\section{REFERENCES}

1. Znini, M.; Cristofari, G.; Majidi, L.; Paolini, J.; Desjobert, J, M; Costa, J. Essential oil composition and antifungal activity of Pulicaria Mauritanica Coss., against postharvest phytopathogenic fungi in apples. LWT - Food Science and Technology 2013, 54, 564-569.

2. Hammiche, V.; Maiza, K. Traditional medicine in Central Sahara: Pharmacopoeia of Tassili N'ajjer. J. Ethnopharmacol. 2006, 105, 358-367.

3. Alaoui, M.S.; Satrani, B.; Ghanmi, M.; Aafi, A.; Amusant, N.; El Antry, S.; Chaouch, A. Bioactivity and chemical quality of Ammodaucus leucotrichus ssp. Leucotrichus Coss. \& Durieu essential oils from Morocco. Nat. Prod. Indian J. 2014, 10, 208-214.

4. Velasco-Negueruela, A.; Perez-Alonso, M, J.; Perez de Paz, P, L.; Pala-Paula, J.; Sanz, J. Analysis by gas chromatography-mass spectrometry of the volatiles from the fruits of Ammodaucus leucotrichus subsp. leucotrichus and subsp. nanocarpus grown in North Africa and The Canary Islands, respectively. J. Chromatogr. A 2006, 1108, 273-275.

5. Sadaoui, N.; Bec, N.; Barragan-Montero, V.; Kadri, N.; Cuisinier, F.; Larroque, C.; Arab, K.; Khettal, B. The essential oil of Algerian Ammodaucus leucotrichus Coss. \& Dur. and its effect on the cholinesterase and monoamine oxidase activities. Fitoterapia 2018, 130, 1-5.

6. Noureddine, H.; Heleno, S.A.; Costa, P.; Fernandes, I.P.; Calhelha, R.C.; Boucherit, K.; Rodrigues, A.E.; Ferreira, I.; Barreiro, M.F. Chemical profile and bioactive properties of the essential oil isolated from Ammodaucus leucotrichus fruits growing in Sahara and its evaluation as a cosmeceutical ingredient. Ind. Crops Prod. 2018, 119, 249-254.

7. Manssouri, M.; Znini, M.; El Harrak, A.; Majidi, L. Antifungal activity of essential oil from the fruits of Ammodaucus leucotrichus Coss. \& Dur., in liquid and vapour phase against postharvest phytopathogenic fungi in apples. J. App. Pharm. Sci. 2016, 6, 131-136.

8. El-Haci, A.; Bekhechi, C.; Atik-Bekkara, F.; Mazari, W.; Gherib, M.; Bighelli, A.; Casanova, J.; Tomi, F. Antimicrobial activity of Ammodaucus leucotrichus fruit oil from Algerian Sahara. Nat. Prod.Commun. 2014, 9, 711-712.

9. Adams, R.P. Identification of Essential Components by Gas Chromatography/Mass Spectroscopy, Allured Corp.: Carol Stream, IL, USA.; 2007.

10. Abu Zarga, M.; Ihlal Al-Jaber, H.; Baba Amer, Z.; Sakhrib, L.; Al-Qudah, M.; Al-humaidi, J.; Abaza, I.; Afifi, F. Chemical composition, antimicrobial and antitumor activities of essential oil of Ammodaucus leucotrichus growing in Algeria. J. Biol. A Prod. Nature 2013, 3, 224-231.

11. Thabrew, M.I.; Robin, D.; Mcfarlane, I.G. Screening of hepatoprotective plant components using a HepG2 cell cytotoxicity assay. J. Pharm. Pharmacol. 1997, 49, 1132-1135.

12. Moustafa, S.M.; Menshawi, B.M.; Wassel, G.M.; Mahmoud, K.; Mounier, M.M. Screening of some plants in Egypt for their cytotoxicity against four human cancer cell lines. Int. J. Pharm. Tech. Res. 2014, 6, 1074-1084.

13. Benchikha, N.; Menaceur, M.; Barhi, Z. In vitro evaluation of antioxidant capacity of Algerian origanum plant by spectrophotometrical and electrochemical assays. Int. J. Pharm. Sci. 2014, 6, 577-580. 
Chemical composition, antimicrobial, antioxidant and anticancer activities of essential oil 549

14. Thakkar, K.N.; Prasad, A.K.; Nayak, J.; Satish, V.; Iyer, S.K. In vitro cytotoxic activity of menispermaceae plants against HeLa cell line. J. Phytopharmacol. 2014, 3, 395-399.

15. Benchikha, N.; Djazi, F. L'activité biologique de six huiles essentielles obtenues par hydrodistillation et de leurs composés majoritaires. Rivista Italiana EPPOS 2007, 44, 39-45.

16. Louail, Z.; Kameli, A.; Benabdelkader, T.; Bouti, K.; Hamza, K.; Krimat, S. Antimicrobial and antioxidant activity of essential oil of Ammodaucus. J. Mater. Environ. Sci. 2016, 7, 2328-2334.

17. Sonboli, A.; Gholipour, A.; Yousefzadi, M. Antibacterial activity of the essential oil and main components of two dracocephalum species from Iran. Nat. Prod. Res. 2012, 26, 21212125.

18. Shiow, Y.W.; Chi-Tsun, C. Effect of allyl isothiocyanate on antioxidant enzyme activities, flavonoids and post-harvest fruit quality of blueberries (Vaccinium corymbosum L., Cv. Duke). Food Chem. 2010, 122, 1153-1158.

19. Ben Amor, M.L.; Benchikha, N.; Elsharkawy, E.R.; Neghmouche nacer, S. Phytochemical characterization, in-vitro cytotoxic and antibacterial activity of Cotula cinerea (Delile) Vis essential oil. J. Nat. Remed. 2018, 18, 107-112.

20. Josphat, C.M.; Joyce J.K.; Nicholas, M.K.; Tiffany, P.H. Chemical composition and antimicrobial activity of the essential oil of Satureja biflora (Lamiaceae). Bull. Chem. Soc. Ethiop. 2007, 21, 249-254.

21. Mosmann, T. Rapid Colorimetric assay for cellular growth and survival: Application to proliferation and cytotoxicity assays. J. Nat. Remed. 1983, 65, 55-63.

22. Rebiai, A.; Lanez, T. In vitro evaluation of antioxidant capacity of Algerian propolis by spectrophotometrical and electrochemical assays. Int. J. Pharmacol. 2011, 7, 113-118.

23. Zouari, N.; Fakhfakh, N.; Zouari, S.; Bougatef, A.; Karray, A.; Neffati, M.; Ayadi, M.A. Food and bioproducts processing chemical composition, angiotensin I-converting enzyme inhibitory, antioxidant and antimicrobial activities of essential oil of Tunisian Thymus algeriensis Boiss. et Reut. (Lamiaceae ). Food Bioprod. Process. 2011, 89, 257-265. 